\title{
THE ESTIMATION OF MAGNESIUM IN SERUM USING TITAN YELLOW
}

\author{
BY \\ D. W. NEILL AND R. A. NEELY \\ From the Department of Biochemistry, Royal Victoria Hospital, Belfast
}

(RECEIVED FOR PUBLICATION MARCH 8, 1955)

Recent work in this laboratory in connexion with a study of idiopathic hypercalcaemia in infants has necessitated the estimation of the magnesium content of serum. For this purpose it was decided to use the Kunkel application of the magnesium-titan yellow lake formation (Kunkel, Pearson, and Schweigert, 1947). Despite repeated attempts it was found impossible to produce coloured solutions in which the red lake was sufficiently stable to permit of reliable colorimeter readings.

As a change in technique was found necessary to overcome this difficulty, it was thought that some attempt should be made at the same time to apply a correction for the presence of calcium in the serum. Kolthoff (1927) stated that as calcium intensifies the colour of the magnesium-titan yellow lake, therefore, the Kunkel technique, based on colorimetric comparisons with pure magnesium standard solutions, should result in an over-estimation of magnesium in serum, while it has been claimed by Garner (1946) that "the presence of calcium in concentrations of the order usually found in blood does not affect the colour produced when read at 5,200 A." On the other hand, it has been shown (Peech and English, 1944 ; Pieters, Hanssen, and Geurts, 1948) that the addition of 100 parts per million of calcium to the solution of magnesium before formation of lake produces maximal, and therefore uniform, intensification of colour. Irrespective of this conflict of views, it would seem that the addition of calcium to the magnesium standards in the concentration found in serum is sufficient to eliminate any "calcium effect."

The lack of stability of the coloured solutions in our hands was thought to be due to the use of hydroxylamine hydrochloride as a colour stabilizer. The same criticism has been made by other workers (Stross, 1942). Substitution of gum ghatti as a protective colloid produced lake suspensions suit- able for colorimetric estimation and stable for at least two hours after development (Garner, 1946).

\section{Experimental}

Solutions.-The following were used :

$0.1 \%$ Gum Ghatti.-Powdered gum ghatti, 0.1 g., is suspended in a muslin bag in $100 \mathrm{ml}$. distilled water for 24 hours. The solution does not deteriorate at room temperature.

$0.05 \%$ Titan Yellow.-The dye powder, $0.1 \mathrm{~g}$., is dissolved in $200 \mathrm{ml}$. distilled water.

Stock Standard Magnesium Chloride.-A quantity, $8.458 \mathrm{~g}$. $\mathrm{MgCl}_{2} \cdot 6 \mathrm{H}_{2} \mathrm{O}$, is dissolved in distilled water and made up to 1 litre. This solution contains 1,000 ,"g. Mg per ml.

Working Standard Magnesium Chloride.-One millilitre stock standard solution is diluted to $200 \mathrm{ml}$. to give a concentration of $5 \mu \mathrm{g}$. magnesium chloride per $\mathrm{ml}$. Volumes of $1,2,3,4$, and $5 \mathrm{ml}$. made up to $5 \mathrm{ml}$. in each case and representing $5,10,15,20$, and $25 \mu \mathrm{g}$. $\mathrm{Mg}$ are used in setting up the standard curve.

Calcium Chloride.-A quantity, $13.88 \mathrm{mg}$. $\mathrm{CaCl}_{2}$, is dissolved in distilled water and made up to $100 \mathrm{ml}$., to give a final concentration of $0.05 \mathrm{mg}$. Ca per $\mathrm{ml}$.

Method.-One millilitre of serum is diluted with $5 \mathrm{ml}$. distilled water. Proteins are precipitated by the addition of $2 \mathrm{ml}$. of $10 \%$ sodium tungstate and $2 \mathrm{ml}$. of $0.67 \mathrm{~N} \mathrm{H}_{2} \mathrm{SO}_{4}$, and the mixture is centrifuged for five minutes at 2,500 r.p.m. To $5 \mathrm{ml}$. of the supernatant is added $1 \mathrm{ml}$. distilled water, $1 \mathrm{ml} .0 .1 \%$ gum ghatti solution, $1 \mathrm{ml} .005 \%$ titan yellow solution, and $2 \mathrm{ml} .4 \mathrm{~N}$. NaOH. The optical density of the red solution is read using an EEL colorimeter with a 624 filter. A blank using $1 \mathrm{ml}$. $\mathrm{CaCl}_{2}$ solution containing $0.05 \mathrm{mg}$. $\mathrm{Ca}$ in place of serum is treated similarly to the test. Readings of optical density are converted to magnesium concentrations by reference to a standard curve. This is prepared by carrying out the above colour reaction on $5 \mathrm{ml}$. samples of solution containing $5,10,15,20$, and $25 \mu \mathrm{g}$. $\mathrm{Mg}$, replacing the $1 \mathrm{ml}$. distilled water added to the protein-free supernatant in the test with $1 \mathrm{ml}$. $\mathrm{CaCl}_{2}$ solution contain- 
ing $0.05 \mathrm{mg}$. Ca. Distilled water, $5 \mathrm{ml}$. is used as a standard blank. Instead of setting up the complete standard curve for each set of estimations a single standard may be used: $2.5 \mathrm{ml}$. of the working $\mathrm{Mg}$ standard containing $12.5 \mu \mathrm{g}$. $\mathrm{Mg}$ is made to $5 \mathrm{ml}$. and treated as the test protein-free supernatant, replacing the $1 \mathrm{ml}$. distilled water with $1 \mathrm{ml}$. $\mathrm{CaCl}_{2}$ solution. The standard blank is $5 \mathrm{ml}$. distilled water.

Calculation.-This is as follows :

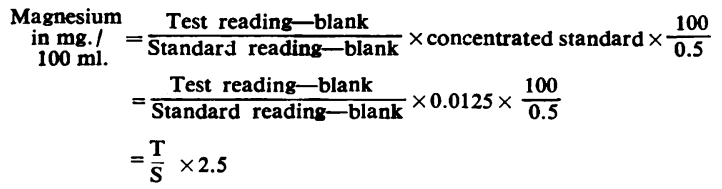

\section{Results}

Comparable standard curves were plotted to demonstrate the effects of adding calcium to magnesium solutions. The tubes were set up as shown in Table I.

TABLE I

PROCEDURE FOR DEMONSTRATING EFFECTS OF ADDING CALCIUM TO MAGNESIUM SOLUTIONS

\begin{tabular}{|c|c|c|c|c|c|c|c|c|c|c|c|c|}
\hline \multirow{2}{*}{ Solutions } & \multicolumn{12}{|c|}{ Tube No. } \\
\hline & 1 & 2 & 3 & 4 & 5 & 6 & 7 & 8 & 9 & 10 & 11 & 12 \\
\hline $\begin{array}{r}\mathrm{Mg}(\mu \mathrm{g} .) \text { in } 5 \\
\text { ml. solution }\end{array}$ & 5 & 10 & 15 & 20 & 25 & - & 5 & 10 & 15 & 20 & 25 & - \\
\hline $\begin{array}{l}\mathrm{Ca} \text { (mg.) in } 1 \\
\text { ml. solution }\end{array}$ & 一 & - & - & - & - & - & 0.05 & 0.05 & 0.05 & 0.05 & 0.05 & 0.05 \\
\hline Water (ml.). & 1 & 1 & 1 & 1 & 1 & 6 & - & - & - & - & - & 5 \\
\hline $\begin{array}{c}1 \% \text { gum ghatti } \\
\text { (ml.) }\end{array}$ & 1 & 1 & 1 & 1 & 1 & 1 & 1 & 1 & 1 & 1 & 1 & 1 \\
\hline $\begin{array}{l}0.05 \% \text { titan } \\
\text { yellow (ml.) }\end{array}$ & 1 & 1 & 1 & 1 & 1 & 1 & 1 & 1 & 1 & 1 & 1 & 1 \\
\hline $\begin{array}{l}\text { 4N.NaOH } \\
\text { (ml.) }\end{array}$ & 2 & 2 & 2 & 2 & 2 & 2 & 2 & 2 & 2 & 2 & 2 & 2 \\
\hline
\end{tabular}

The curves obtained are shown in Fig. 1 and illustrate both the applicability of the LambertBeer law within the concentration range likely to be encountered in human sera, and the colourintensifying effect of added calcium.

Estimations of magnesium in 50 normal sera based on these standard curves gave the following results :

$\mathrm{Mg}$ (mg./100 ml. serum) standards containing $\mathrm{Ca}$ : mean 2.3 , range $1.9-2.7$.

$\mathrm{Mg}$ (mg./100 ml. serum) standards alone : mean 2.8, range 2.2-3.6.

Failure to allow for the effect of the calcium in serum thus results in an apparent elevation of the magnesium content of about $0.5 \mathrm{mg}$. per $100 \mathrm{ml}$.

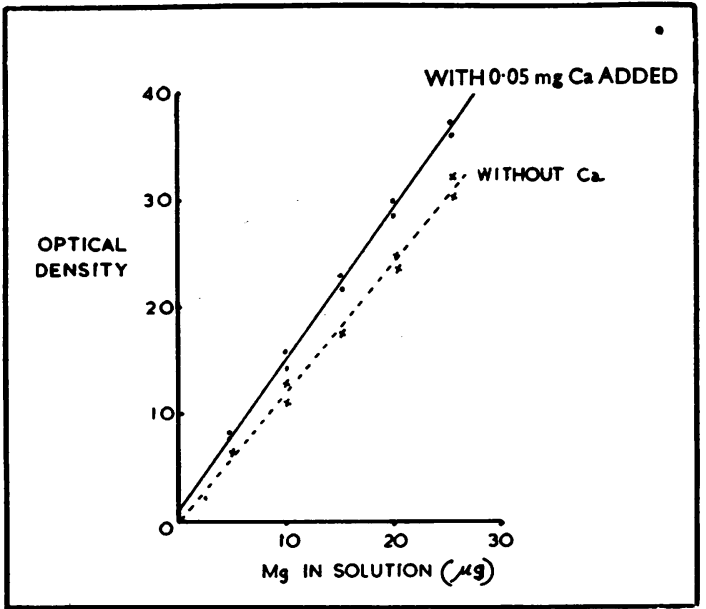

FIG. 1.-Standard curves showing the effect of adding $\mathrm{Ca}$ to $\mathrm{Mg}$ solutions.

Duplicate estimations on 20 sera gave the following figures :

Mean $2.45 \pm 0.24 \mathrm{mg}$. $\mathrm{Mg}$ per $100 \mathrm{ml}$.

Recovery experiments carried out to assess the efficiency of the technique yielded the results shown in Table II.

TABLE II

RECOVERY OF MG ADDED TO SAMPLES OF SERUM

\begin{tabular}{c|c|c}
\hline $\begin{array}{c}\text { Test } \\
\text { No. }\end{array}$ & $\begin{array}{c}\text { Mg Added } \\
\text { (mg. per 100 ml.) }\end{array}$ & $\begin{array}{c}\% \\
\text { Recovery }\end{array}$ \\
\hline 1 & 0 & $\overline{98}$ \\
2 & 0.5 & 95.3 \\
3 & 1.0 & $100 \cdot 0$ \\
4 & 2.0 & 92.8 \\
5 & 4.0 & \\
\hline
\end{tabular}

\section{Summary}

The titan yellow method for estimating serum magnesium is modified by the addition of calcium to the magnesium standard solutions, and by the use of gum ghatti in place of hydroxylamine hydrochloride as a colour stabilizer.

The normal adult magnesium level in serum by this technique is $1.9-2.7 \mathrm{mg}$. per $100 \mathrm{ml}$. (mean 2.3).

We are grateful for the advice and assistance of Dr. J. A. Smyth, under whose direction this work was undertaken, and are indebted to Dr. R. A. Womersley for helpful discussions.

\section{REFERENCES}

Garner, R. J. (1946). Biochem. J., 40, 828

Kolthoff, J. M. (1927). Biochem. Z., 185, 344.

Kunkel, H. O., Pearson, P. B., and Schweigert, B. S. (1947). J. Lab. clin. Med., 32, 1027.

Peech, M., and English, L. (1944). Soil Sci., 57, 167

Pieters, H. A. J., Hanssen, W. J., and Geurts, J.' J. (1948). Analyt. chim. Acta, 2, 241.

Stross, W. (1942). Analyst, 67, 317. 